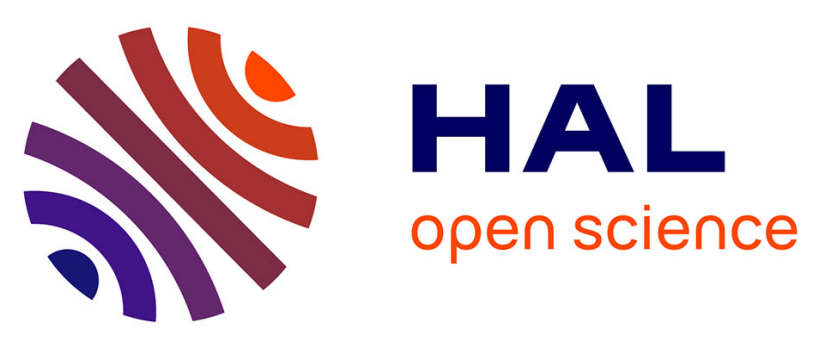

\title{
Design and Synthesis of Two-Photon Responsive Chromophores for Near-Infrared Light-Induced Uncaging Reactions
}

\author{
Manabu Abe, Youhei Chitose, Satish Jakkampudi, Pham Thi Thu Thuy, \\ Qianghua Lin, Bui Thi Van, Ayato Yamada, Ryoko Oyama, Miyu Sasaki, \\ Claudine Katan
}

\section{To cite this version:}

Manabu Abe, Youhei Chitose, Satish Jakkampudi, Pham Thi Thu Thuy, Qianghua Lin, et al.. Design and Synthesis of Two-Photon Responsive Chromophores for Near-Infrared Light-Induced Uncaging Reactions. Synthesis: Journal of Synthetic Organic Chemistry, 2017, Special Issue Dedicated to Professor Herbert Mayr, 49 (15), pp.3337-3346. 10.1055/s-0036-1590813 . hal-01573424

HAL Id: hal-01573424

https://hal-univ-rennes1.archives-ouvertes.fr/hal-01573424

Submitted on 29 Oct 2018

HAL is a multi-disciplinary open access archive for the deposit and dissemination of scientific research documents, whether they are published or not. The documents may come from teaching and research institutions in France or abroad, or from public or private research centers.
L'archive ouverte pluridisciplinaire HAL, est destinée au dépôt et à la diffusion de documents scientifiques de niveau recherche, publiés ou non, émanant des établissements d'enseignement et de recherche français ou étrangers, des laboratoires publics ou privés. 


\section{Design and Synthesis of Two-Photon Responsive Chromophores for Near-Infrared Light-Induced Uncaging Reactions}

\author{
Manabu Abe*a \\ Youhei Chitose ${ }^{a}$ \\ Satish Jakkampudi ${ }^{\text {a }}$ \\ Pham Thi Thu Thuy ${ }^{a}$ \\ Qianghua $\operatorname{Lin}^{\mathrm{a}}$ \\ Bui Thi Van ${ }^{a}$ \\ Ayato Yamada ${ }^{a}$ \\ Ryoko Oyama $^{a}$ \\ Miyu Sasaki ${ }^{\text {a }}$ \\ Claudine Katan ${ }^{* b}$ \\ a Department of Chemistry, Graduate School of Science, \\ Hiroshima University, 1-3-1 Kagamiyama, Higashi-Hiroshima, \\ Hiroshima 739-8526, Japan \\ b Institut des Sciences Chimiques de Rennes, UMR6226, CNRS, \\ Université de Rennes 1, Ecole Nationale Supérieure de Chimie \\ de Rennes, INSA de Rennes, 35042 Rennes, France \\ *mabe@hiroshima-u.ac.jp; claudine.katan@univ-rennes1.fr
}

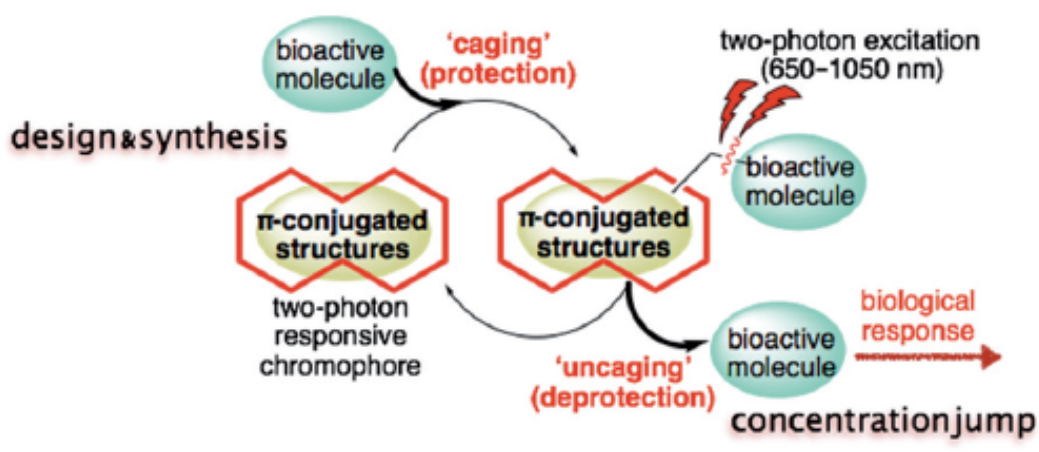

Dedicated to Professor Herbert Mayr on the occasion of his $70^{\text {th }}$ birthday
Abstract Near-infrared two-photon (TP)-induced photorelease (un- caging) of bioactive molecules such as drugs has attracted considerable attention because of its ability to elucidate mechanistic aspects of bio- logical processes. This short review summarizes recent developments in the design and synthesis of TP-responsive chromophores.

\section{Introduction}

2 Molecular Design of TP-Responsive Organic Chromophores for

'Caging \& Uncaging'

$2.1 \pi$-Conjugation

2.2 A Dipolar System

2.3 A Quadrupolar System

2.4 An Octupolar System

3 Recent Developments of TP Uncaging Reactions

3.1 4-Methoxy-7-nitroindolinyl Caged Auxins

3.2 Uncaging of GABA and Tryptophan Using TP-Induced Electron-

Transfer Reactions

3.3 Effect of Position Isomery in Aminoquinoline-Derived Photolabile Protecting Groups (PPGs)

3.4 Cooperative Dyads for TP Uncaging

3.5 Caged Calcium with a Bis-styrylthiophene Backbone

3.6 Cloaked Caged Compounds

3.7 Three-Dimensional Control of DNA Hybridization by Orthogonal

Two-Color TP Uncaging

3.8 TP-Induced Release of Diethyl Phosphate (DEP) and ATP

4 Our Contribution to TP Uncaging Reactions

5 Summary

Key words caging reactions, uncaging reactions, photolabile protect- ing groups, two-photon absorption, time-dependent density functional theory

\section{Introduction}

In general, two principle methods are used to investigate the role of biologically active compounds and their as- sociated mechanisms in biological processes: (1) imaging, and (2) caging $\&$ uncaging. Fluorescence microscopic tech- niques that use biological fluorescent stains, immunofluorescence, and fluorescent proteins can be utilized to generate real-time images of life phenomena, from which the active sites and functionalization of bioactive compounds can be clarified.1 This method is widely employed in biological and physiological studies. 2

Another technique used to investigate in vivo activity involves concentration jumps of bioactive molecules.3 Since biological responses induced by such concentration jumps ceases within the micro- to millisecond timescale, spatiotemporal control of the release of bioactive molecules is necessary in physiological studies. Approximately 40 years ago, Schlaeger,4 Hoffmann5 and their co-workers, who were biochemists, developed a 'caging \& uncaging' method for bioactive substances (Figure 1), in which the bioactive molecules are temporally inactivated (caged) by photolabile protecting groups (PPGs)6-11 and re-activated (uncaged) by flash photolysis of the caged compounds. For this reason, the meaning of 'caging \& uncaging' is not derived from the shape of molecules, rather it signifies the 'masking (inactivation) \& unmasking (activation)' of biologically active sub- stances such as therapeutic drugs.

To date, several types of PPGs have been used in physiological studies investigating the phenomena of life (Figure 2), which can be categorized into two groups based on the photorelease uncaging mechanism: (1) Those in which the release is the consequence of an intramolecular rearrangement (nitrophenyl, or cinnamyl-type PPGs), and (2) PPGs that are cleaved directly by SN1-type solvent-assisted photolysis; the latter offering inherently faster release. The orthonitrobenzyltype PPG (o-NB)12-14 was the first PPG in the 'caging \& uncaging' technique in physiological studies.

However, this PPG has the potential to thermally hydrolyze at the benzylic position to produce bioactive substances during such studies. To avoid such a possibility, Specht, Goeldner and co-workers used an ortho-nitrophenethyl (o- NPE)15-18 PPG for their physiological studies. The PPG was developed by Hasan 


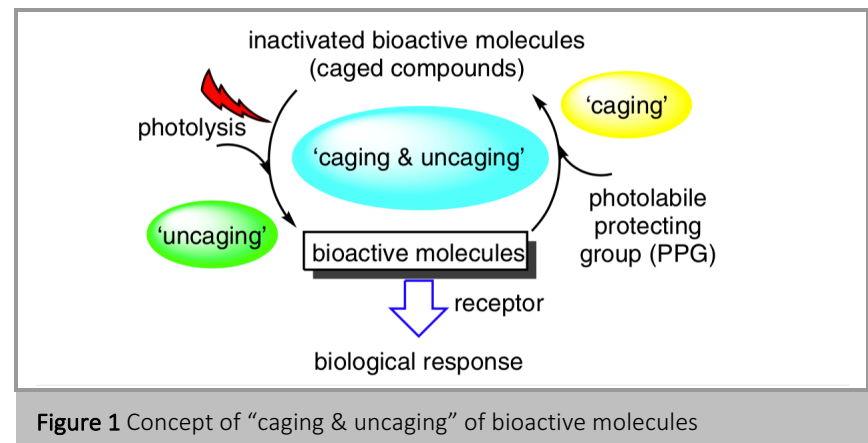

and co-workers.15 Nitro-substituted indoline derivatives19-24 have also been used for the uncaging reactions.

Givens and co-workers developed a photo-SN1-type of uncaging step using coumarin chromophores (Figure 2).25,26 Quinoline derivatives27-30 have also been used for the SN1type photorelease of drugs. Kakiuchi and co-workers have discovered a novel chromophore employing a thiochromone for the uncaging step.31 Very recently, new visible- lightresponsive PPGs with fluorescent character, i.e., BODIPY and bimane, were developed by Smith, Winter, Klán, and Singh.32 In this case, acids $[\mathrm{X}=-\mathrm{OC}(0) \mathrm{R}]$ can be released by the visible light. Furthermore, Marchán et al. developed new coumarinderived chromophores (DEDCC) having visible-light responsiveness.32d,e Jana, Singh, and co- workers used a carbazole (CBZ) unit for the release of single and dual carboxylic acids.32f

After the pioneering studies by Schlaeger and Hoffmann in the late 1970s, the 'caging \& uncaging' technique has become a general tool for physiological studies, including neurological science, cell biology, gene expression, and structural biology. In the mid-1990s, the second generation of 'caging \& uncaging' technology emerged, employing a two- photon (TP) excitation process with light at $\sim 700-750 \mathrm{~nm}$. Note that living tissues are almost transparent (low absorption) to light from the nearinfrared (NIR) region, i.e. be- tween 650-1050 nm. Denk,33,34 Lipp and Niggli,35 Furuta and Tsien,36 and Ellis-Davies and Kasai37 were the contributors to this revolution, which provided this next generation of 'caging \& uncaging' technology based on NIR-TP irradiation. For in vivo studies, caged compounds in general should be water-soluble and non-toxic. In addition to the basic conditions, it is becoming essential to have large TP responses from the chromophores.

The physicist Maria Göppert-Mayer laid down the theoretical foundation of the TP excitation process in 1931,38 in which two photons are absorbed simultaneously by the same molecule. This is illustrated for Ar-X in Figure 3. Thanks to its strong one-photon (OP) absorption band at $400 \mathrm{~nm}(3.10 \mathrm{eV})$, the molecule can be electronically excited by irradiation at 400 $\mathrm{nm}$ to generate the corresponding excited state $[\mathrm{Ar}-\mathrm{X}]^{*}(\mathrm{~S} 1)$ (Figure 3 ). Of course, the excited state molecule $[\mathrm{Ar}-\mathrm{X}]^{*}$ cannot be generated using an $800 \mathrm{~nm}$ OP excitation process, because the molecule has a vanishing OP absorption at $800 \mathrm{~nm}(1.55 \mathrm{eV})$, that is, the absorbance is zero at $800 \mathrm{~nm}$ (Figure 3). However, using ultra- short pulses with high light intensity (typically via a femtosecond pulsed laser), molecules having TP absorption character can absorb simultaneously two photons, in this case at $800 \mathrm{~nm}$, to generate the same molecular excited state $[\mathrm{Ar}-\mathrm{X}]^{*}$.

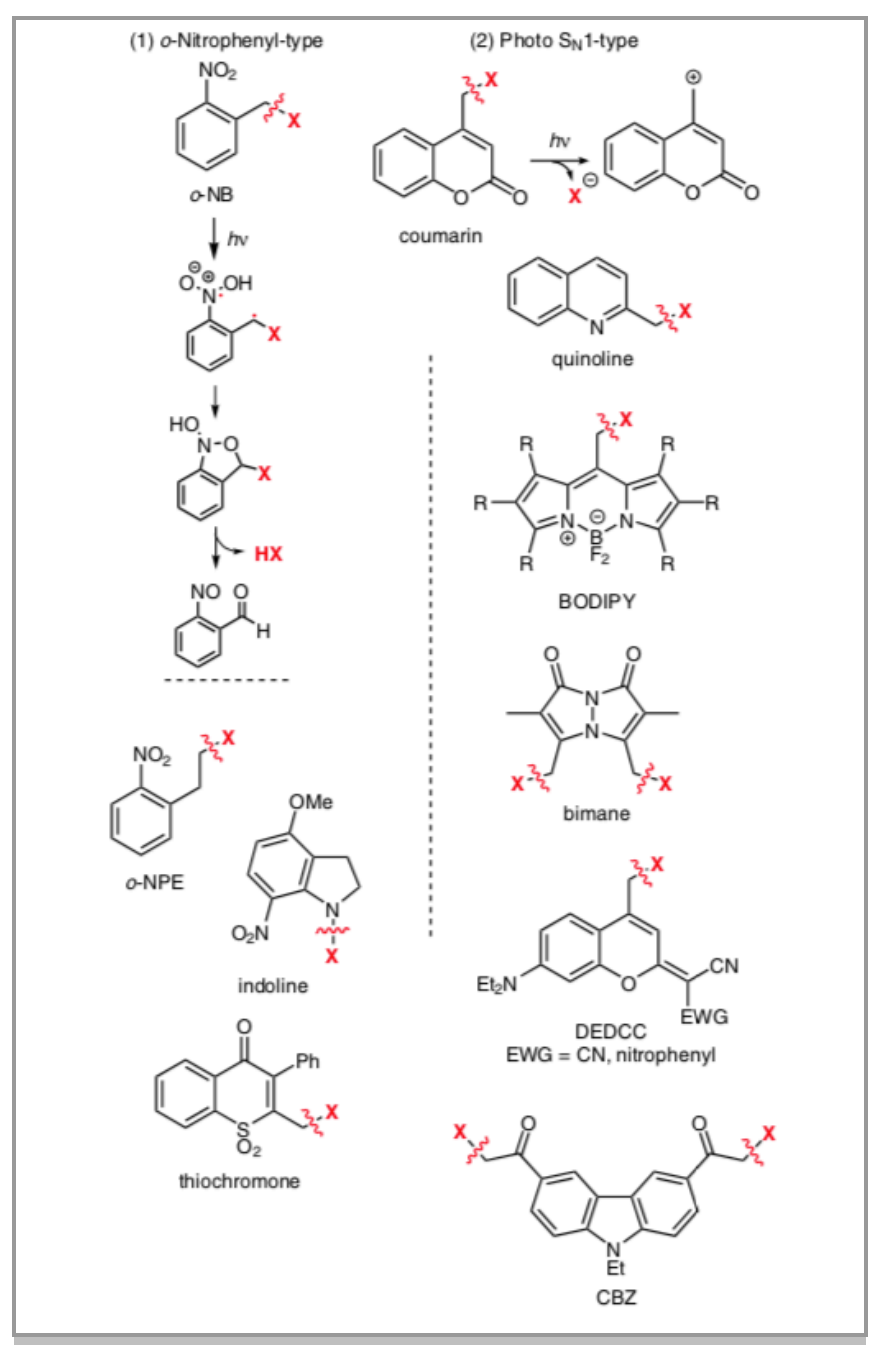

Figure 2 Selected types of photolabile protecting groups (PPGs)

Thus, in the TP excitation process, much lower energy photons can be used to bring molecules to their electronically excited state $[\mathrm{Ar}-\mathrm{X}]^{*}(\mathrm{~S} 1)$. Half the energy $\left(h v^{\prime}=1 / 2 \times h v\right)$ of the corresponding OP excitation $(E=h v)$ can be used when the first electronic excitation band (S1) of the OP excitation process is allowed for the TP excitation process.

The efficiency of the TP absorption process is quantified by the TP cross-section ( $\sigma 2)$, its magnitude being expressed using the Göppert-Mayer (GM) unit, $1 \mathrm{GM}=10-50 \mathrm{~cm} 4 \mathrm{~s}$ photon-1 molecule-1 (Figure $4, \mathrm{a}$ ). The uncaging efficiency $(\delta \mathrm{u})$ of the TP excitation process is determined by the equation $\delta u=\sigma 2 \times \varphi \mathrm{u}$, where $\varphi \mathrm{u}$ is the quantum yield of the un- caging reaction. The advantages of using the NIR-TP excitation process in place of one-photon (OP) excitation with UV-vis light include: (1) less photo-damage to living tissue, (2) higher three-dimensional (3D) spatial resolution, (3) deeper penetration in turbid tissues, and (4) lower light scattering.

With a TP excitation process, only molecules located at the focal point will be excited (Figure $4, \mathrm{~b}$ ), since the probability $(P)$ of excitation is proportional to the light intensity $(I)$ squared.39 Conversely, all illuminated molecules will be excited with an OP excitation process. Thus, 3D spatial selective excitation is possible using the TP excitation technique, although a highintensity femtosecond laser is re- quired.40,41 


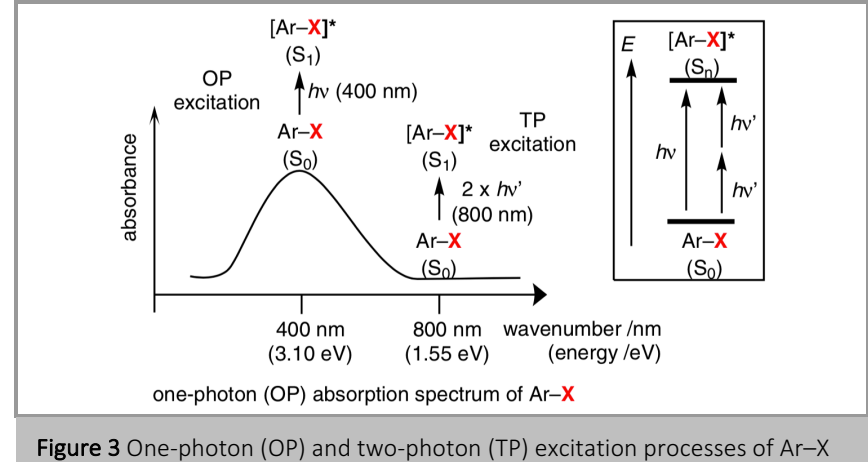

In this short review, the basic strategies for designing TPresponsive chromophores for in vivo studies are first provided, followed by a summary of very recent developments in the TP uncaging technology using NIR light, including our contributions from the last three years, since excellent earlier reviews are also available.42-49

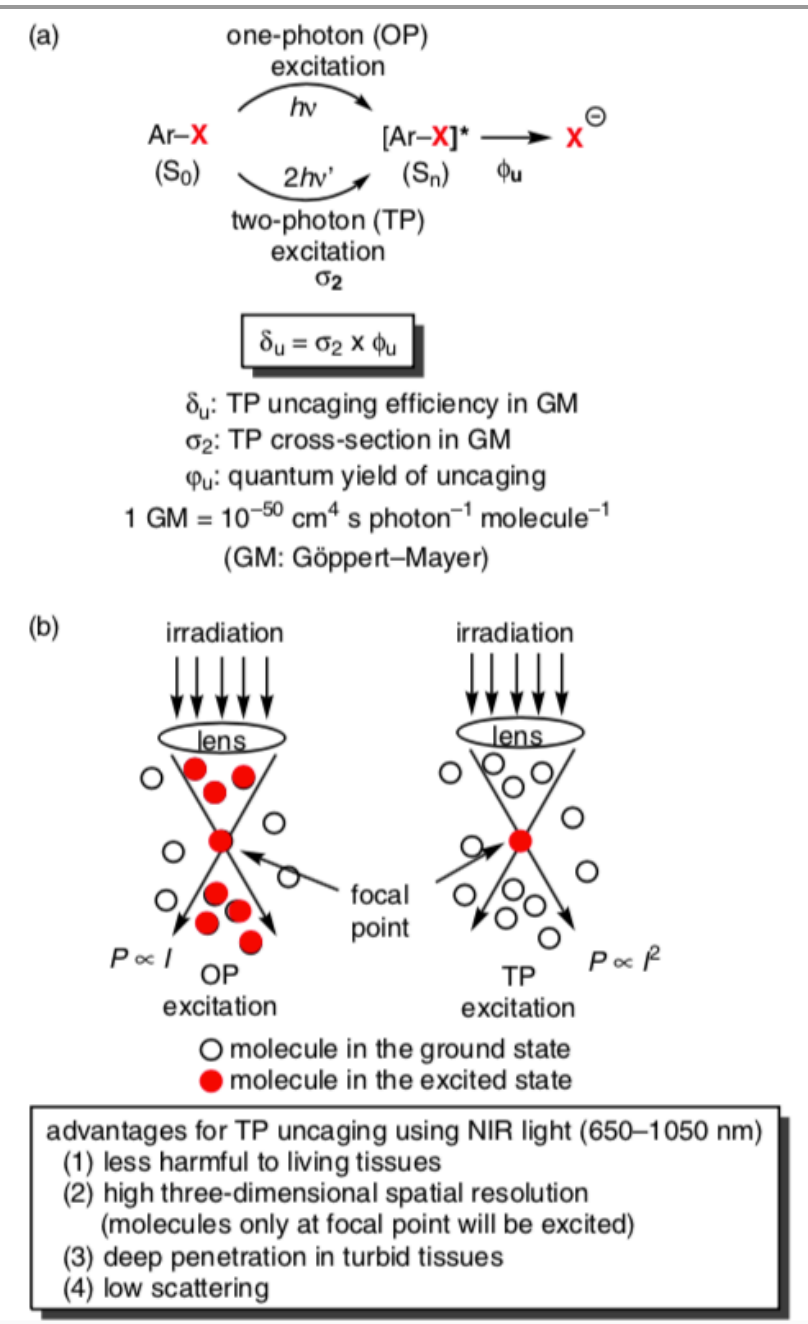

Figure 4 (a) TP uncaging reaction and (b) advantages of TP excitation versus OP excitation

In this short review, the basic strategies for designing the TP-responsive chromophores in vivo studies are first provided, followed by a summary of very recent developments in the TP uncaging technology using NIR light, including our contributions, in the last three years, since excellent earlier reviews are also available. ${ }^{42-49}$

\section{Molecular Design of TP-responsive Organic Chromophores for "Caging \& Uncaging"}

Essentially, four strategies have been developed to de- sign chromophores with smart TP absorption character: (1) $\pi$ conjugation, and (2) dipolar, (3) quadrupolar and (4) octupolar systems (Figure 5).50 Besides, in terms of biological applications, it is useful to find out how the excitation wavelength in the NIR region of light (650-1050 nm) can be selected. In this regard, time-dependent density functional theory (TDDFT) has proved to be a powerful theoretical method for designing appropriate chromophores based on predicted TP absorption spectra. $50-52$

(a) $\pi$-conjugation

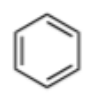

$\sim 0 \mathrm{GM}$

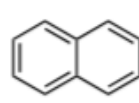

$0.9 \mathrm{GM}$ $(530 \mathrm{~nm})$

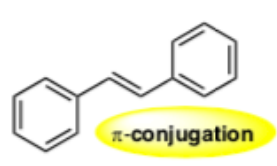

12 GM (514 nm) (b) dipolar system

D- $\pi-\mathbf{A}$

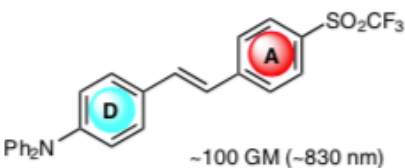

$\sigma_{2} \propto \mu^{2}{ }_{g e}\left(\mu_{e e}-\mu_{g g}\right)^{2}$

(c) quadrupolar system D $-\pi-A-\pi-D$ (A- $\pi-\mathrm{D}-\pi-\mathbf{A})$<smiles>CCCCNc1ccc(/C=C/c2ccc(N(CC(C)C)C(C)(C)C)cc2)cc1</smiles>

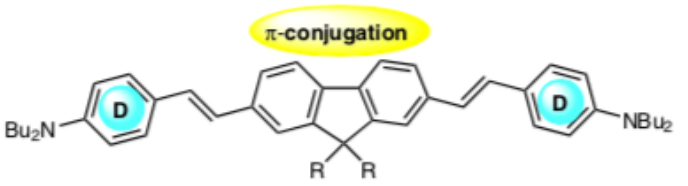

$1300 \mathrm{GM}(740 \mathrm{~nm})$

(d) octupolar system $\mathbf{D}(-\pi-\mathbf{A})_{3}$ $\left[\mathbf{A}(-\pi-\mathbf{D})_{3}\right]$
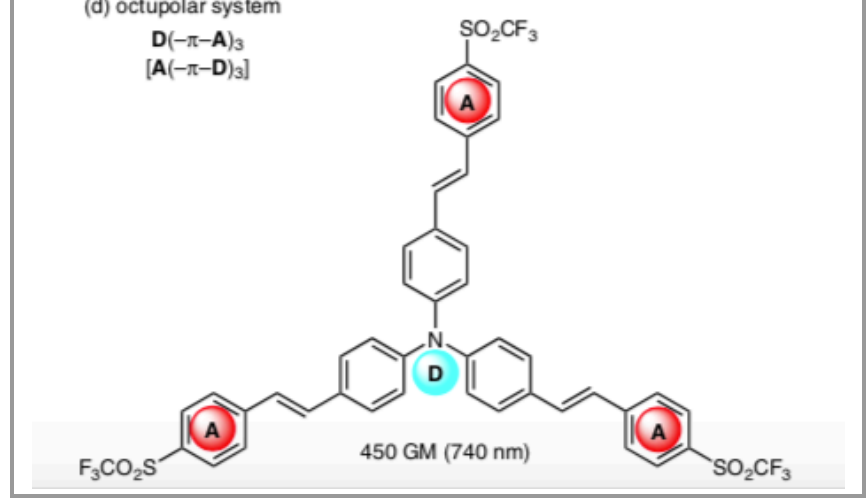

Figure 5 Strategies to induce TP absorption character into molecules

\section{1. $\pi$-Conjugation}

First, benzene possesses no TP-responsive character. Naphthalene shows slight TP absorption character, with 0.9 GM 
at $530 \mathrm{~nm} .53$ Stilbene, in which two benzene rings are connected by a double bond, demonstrates a sizable TP response, $12 \mathrm{GM}$ at $514 \mathrm{~nm}$ (Figure 5, a).54 This basic trend clearly shows that the $\pi$-conjugation is directly correlated with TP absorption character.

\subsection{A Dipolar System}

The introduction of an electron-donating substituent (D) and an electron-withdrawing substituent (A), at either ends of stilbene, leads to a molecule with dipolar character (D- $\pi-A)$. Figure 5 (b) highlights the dramatic increase in TP absorption cross-section, with $100 \mathrm{GM}$ at $\sim 830 \mathrm{~nm}$, i.e., a wavelength of twice that of the OP absorption maximum at $\sim 410 \mathrm{~nm} .55$ The one order of magnitude increase of the TP cross-section obtained with the push-pull structure can be rationalized within a two-state model, in which the cross section $(\sigma 2)$ is proportional to the product of the squared transition dipole moment and the squared difference be- tween the excited-state and ground-state dipole moments (Figure 5, b, eq 1).50

\subsection{A Quadrupolar System}

Quadrupolar character (i.e. $\mathrm{D}-\pi-\mathrm{A}-\pi-\mathrm{D}$ or $\mathrm{A}-\pi-\mathrm{D}-\pi-\mathrm{A}$ ) arises in a stilbene structure by introducing push-push or pullpull substituent designs at either end of the core skeletal structure (Figure 5, c).56 For example, a large $\sigma 2$ value of 110 GM was reported at $620 \mathrm{~nm}$ for a push-push structure. When the $\pi$-conjugation increases by introducing a fluorenyl core between two stilbenes moieties, $\sigma 2$ undergoes a more than tenfold enhancement accompanied by significant red-shift, leading for instance to $1300 \mathrm{GM}$ at $740 \mathrm{~nm} .57 \mathrm{~A}$ three-state model can be used to rationalize the TP response of such quadrupolar systems.

The TP absorption maxima of quadrupolar systems do not show up at twice the wavelength of the OP absorption peaks, since the selection rules for optical transitions are different for $\mathrm{OP}$ and TP processes in centrosymmetric structures.44,50 Often, the first TP absorption maximum shows up at a smaller wavelength than twice the first $\mathrm{OP}$ absorption maximum (i.e., $\lambda \mathrm{TP}<2 \times \lambda \mathrm{OP}$ ).

\subsection{An Octupolar System}

Triangular structures such as 1,3,5-trisubstituted-benzene [i.e., $D(-\pi-A) 3$ or $A(-\pi-D) 3$ ] demonstrate an octupolar character via the introduction of push (D) or pull (A) substituents (Figure 5, d). Such octupolar structures also lead to sizable $\sigma 2$ values, for example, of more than 1000 GM above $\sim 740 \mathrm{~nm}$ for the chromophores shown Figure 5 (d).55,58

As briefly described above, both state and transition dipole moments of the molecule play crucial roles in producing molecules with high multi-photon absorption character. The absorption spectra of the TP excitation process can be predicted by TD-DFT calculations, at least qualitatively depending on available levels of theory.50 For dipolar systems, the first TP absorption maxima is expected to show up at twice the wavelength of the first OP absorption maxi- mum, both processes being symmetry allowed. Often this involves excitation to the first excited state (S1). For quadrupolar and octupolar structures, the first TP allowed electronic transition usually corresponds to a higher electronic excited state such as
S2 or S3, in which the transition dipole moments may be vanishing.50,55,58

Increasing $\pi$-conjugation not only increases the TP absorption cross-section values of molecules, but also their hydrophobicity. However, caged compounds must possess suitable water solubility in physiological studies. Further- more, the TP absorption maxima should be in the NIR region of 650$1050 \mathrm{~nm}$. Thus, a balance of TP absorption character and water solubility must be considered when designing TP-responsive chromophores for physiological studies.

In addition to the above-mentioned requirements for state-of-the-art caged compounds, i.e., TP responsiveness, water solubility and non-toxicity, the rate of photorelease of bioactive molecules is also a very important issue for physiological experiments. The sharp concentration jump by photolysis, e.g., less than a microsecond timescale, is es- sential for observing fast biological responses.

\section{Recent Developments of TP Uncaging Reactions}

\subsection{4-Methoxy-7-nitroindolinyl (MNI)-Caged Auxins}

The plant hormone auxin (i.e., indole-3-acetic acid) plays a crucial role in almost every aspect of plant development. Hayashi and co-workers59 have designed and synthesized a 4methoxy-7-nitroindolinyl (MNI)-caged auxin (Scheme 1). The caged auxin was found to be thermally stable in plants, and indole-3-acetic acid was released rapidly upon photolysis. However, the $o$-NPE-caged auxin was found to be unstable in plants. The authors determined optical control of auxinresponsive gene expression and aux- in-related physiological responses using the TP-responsive caged auxin.

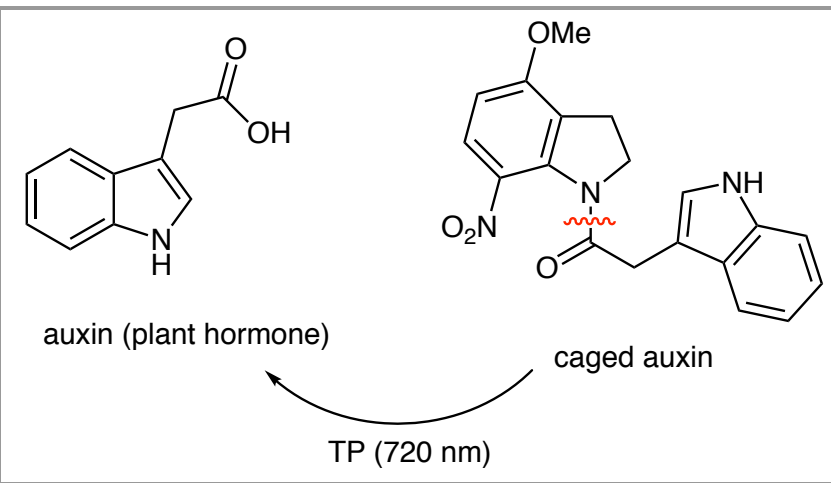

Scheme 1 TP uncaging reaction of caged auxin

\subsection{Uncaging of GABA and Tryptophan Using TP-} induced Electron-Transfer Reactions

Anderson and co-workers60 developed a new approach for the design of TP-responsive chromophores based on a photoinduced electron-transfer reaction (Scheme 2). They succeeded in synthesizing TP-responsive caged $\gamma$-amino butyric acid (GABA) and L-tryptophan (Trp) with an electrondonating fluorene-based chromophore and an electronaccepting pyridinium moiety. A high TP cross-section value of $\sigma 2=1100 \mathrm{GM}$ at $700 \mathrm{~nm}$ was found for GABA. Further, a clean photochemical release of GABA was observed at $700 \mathrm{~nm}$ irradiation with a chemical yield of $>95 \%$ and a photo chemical yield of $1 \%(\varphi \mathrm{u}=0.01)$. Thus, the efficiency of the TP-induced 
uncaging reaction of GABA was determined to be $\delta \mathrm{u}=10 \pm 3$ GM.

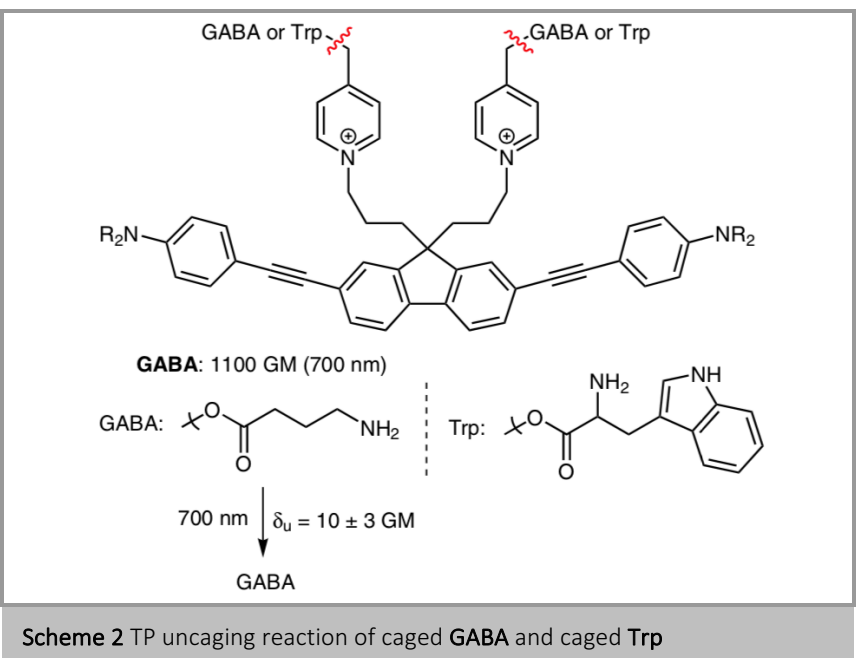

3.3. Effect of Position Isomerism in Aminoquinoline-Derived PPGs

Substituent effects on the TP-induced uncaging reaction were reported by Dalko and co-workers61 for TP-responsive aminoquinoline derivatives (Scheme 3). The TP uncaging efficiency at $730 \mathrm{~nm}$ for the C5-carboxy isomer $\mathbf{5 C O 2 H}, \delta \mathrm{u}=$ $0.11 \mathrm{GM}$, was much smaller than the parent $\mathbf{H}(\delta \mathrm{u}=0.67 \mathrm{GM})$, $\mathbf{5 B z}(\delta \mathrm{u}=2.0 \mathrm{GM})$, and $\mathbf{5 A c r}(\delta \mathrm{u}=0.25 \mathrm{GM})$, even though the substituent is supposed to induce a higher intramolecular charge-transfer character than the parent $\mathbf{H}$.

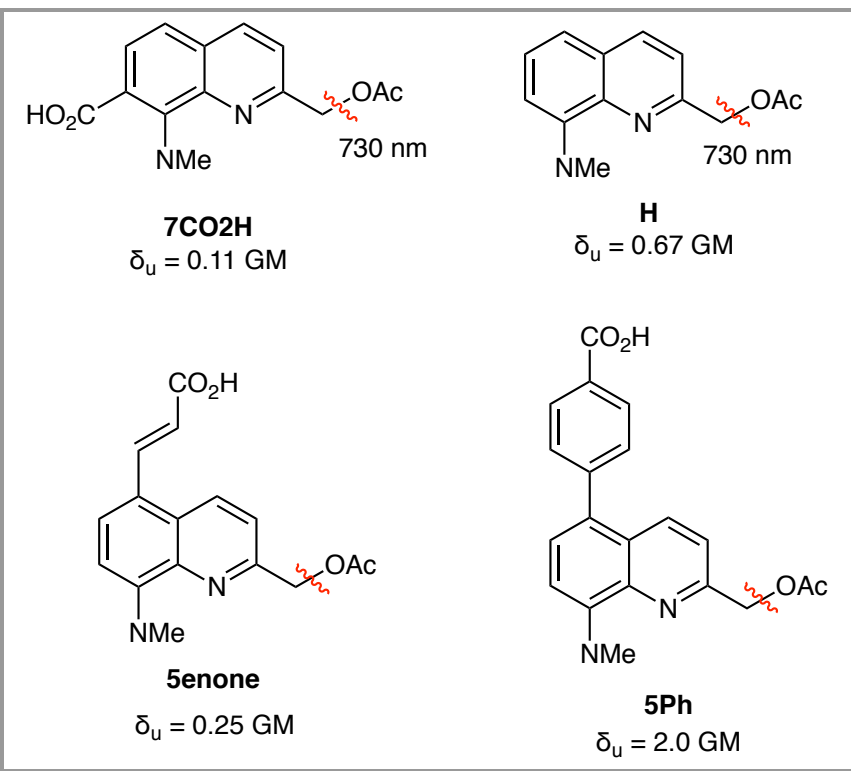

Scheme 3 TP uncaging reaction of quinolone derivatives

\subsection{Cooperative Dyads for TP Uncaging}

Blanchard-Desce and co-workers62 designed an intramolecular energy transfer system from the TP-responsive chromophore to the PPG unit. Donor-donor substituted $(\mathrm{R}=$ $\mathrm{NR} 2, \mathrm{OR})$ and acceptor-acceptor substituted ( $\mathrm{R}=\mathrm{SO2CF} 3)$ fluorene structures with quadrupolar characters were chosen for the TP-responsive chromophore (Scheme 4), and the 4methoxy-2-nitrophenyl unit was used for uncaging. The NIR-TP- induced release of acetic acid (AcOH) was examined at 720-800 $\mathrm{nm}$. The uncaging efficiency of the donor- donor substituted compound was found to provide the best TP uncaging efficiency of $\delta \mathrm{u}=0.25 \mathrm{GM}(\sigma 2=310 \mathrm{GM})$ at $800 \mathrm{~nm}$.

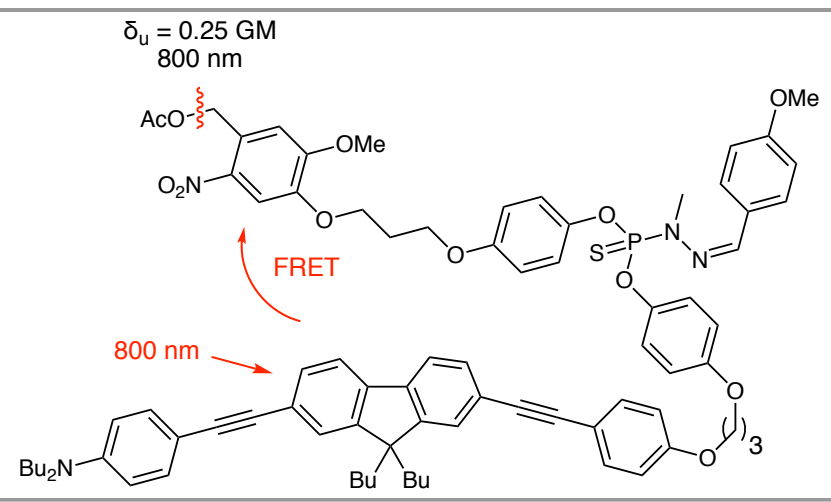

Scheme 4 TP-induced energy transfer and uncaging reaction of acetic acid. FRET: fluorescence resonance energy transfer

\section{Backbone}

3.5. Caged Calcium with a Bisstyrylthiophene

Calcium ions (Ca2+) have many crucial roles in the physiology and biochemistry of organisms and cells. For example, in signal transduction pathways, $\mathrm{Ca} 2+$ acts as a second messenger in neurotransmitter release from neurons. Therefore, cagedcalcium compounds have attracted considerable attention in the field of neuroscience. Since Ca2+ cannot be covalently bound to organic chromophores, an ethylene glycol tetraacetic acid (EGTA) unit has been used as the in vivo Ca2+-selective chelator. Ellis-Davies and co- workers63 were the first to develop TP uncaging of Ca2+ us- ing a nitrodibenzofuran structure. In 2016, this group developed a new EGTA-substituted chromophore with TP ab- sorption character in the NIR region; specifically a dinitro derivative of bis-styrylthiophene (Scheme 5). The bisnitro- styryl structure provided a sizable TP cross-section of 350 $\mathrm{GM}$ at $775 \mathrm{~nm}$. Moreover, the $\mathrm{Ca} 2+$ chelator was found to release $\mathrm{Ca} 2+$ in $<0.2 \mathrm{~ms}$ upon flash photolysis.

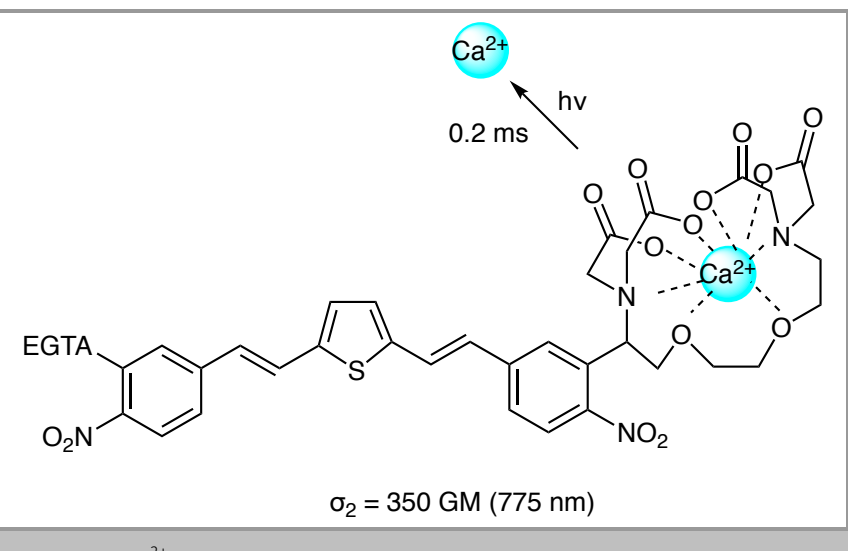

Scheme $5 \mathrm{Ca}^{2+}$ uncaging reaction using a high TP-responsive chromophore

\subsection{Cloaked Caged Compounds}

Ellis-Davies and co-workers64 invented cloaked caged compounds (e.g., G5-DEAC450-GABA), in which antagonists of ionotropic $\gamma$-aminobutyric acid (GABA) were cloaked in a fifth generation of a 2,2-bis(methylol)propionic acid dendrimer 
conjugated molecule (Scheme 6). Using the cloaked caged GABA compound, a physiological study of the signaling of the inhibitory neurotransmitter GABA became possible in its natural state for the first time.

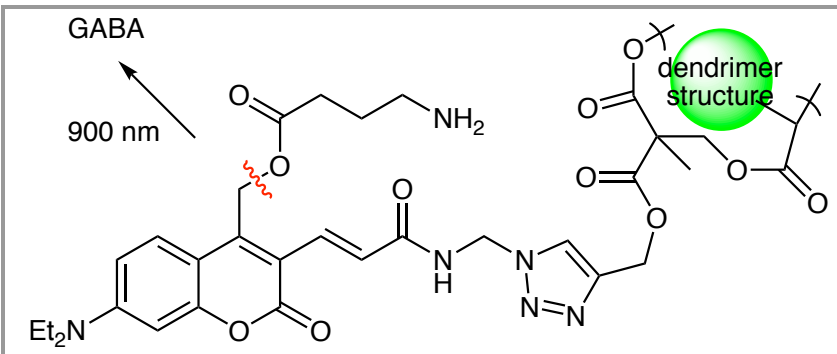

Scheme 6 TP-induced ( $900 \mathrm{~nm}$ ) uncaging reaction of GABA

3.7. Three-Dimensional Control of DNA Hybridization by Orthogonal Two-Color TP Uncaging

Heckel and co-workers65 reported the three-dimension- al control of DNA hybridization using TP uncaging reactions of DNA-1 and DNA-2 (Scheme 7). In this study, DNA strands were introduced into TP-responsive chromophores such as [7(diethylamino)coumarin-4-yl]methyl and $p$-dialkylaminonitrobiphenyl chromophores. These 3D uncaging reactions demonstrated that the technique is feasible for more complex scenarios. DNA-1 can be uncaged at $840 \mathrm{~nm}$, and DNA-2 can be uncaged at $980 \mathrm{~nm}$, thus, selective uncaging was found to be possible by simply changing the excitation wavelength.

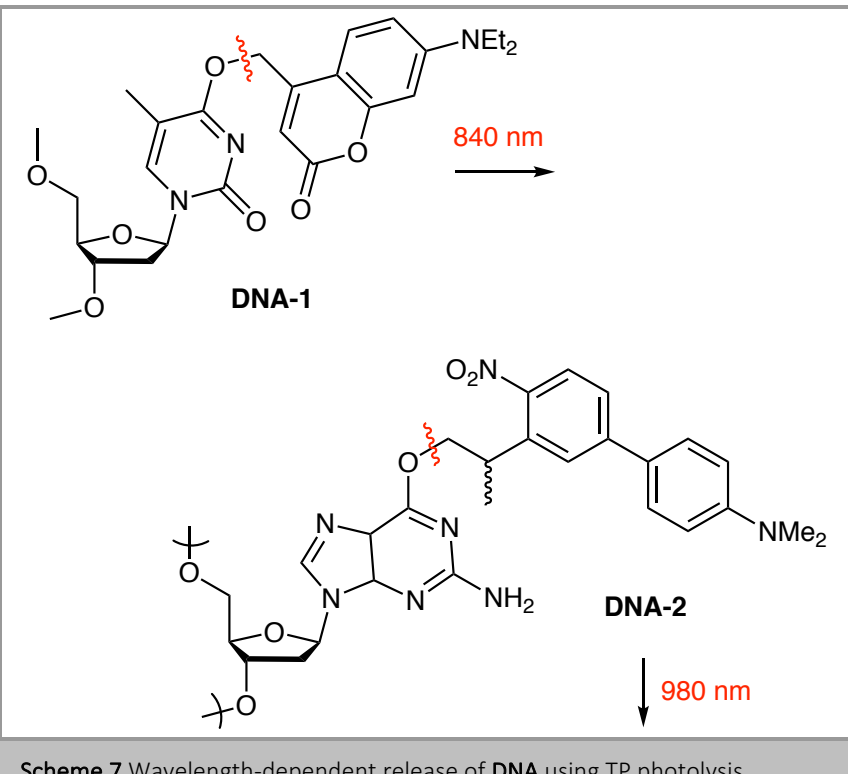

Scheme 7 Wavelength-dependent release of DNA using TP photolysis

\subsection{TP-Induced Release of Diethyl Phosphate (DEP) and ATP}

The first TP activation of $p$-hydroxyphenacyl ( $p \mathrm{HP}$ ) PPG66a,b was reported by Houk, Givens, and Elles67 (Scheme 8). A strong TP absorption ( $>10 \mathrm{GM}$ ) was observed at $\sim 550 \mathrm{~nm}$. Monitoring the progress of the uncaging reaction of di- ethyl phosphate (DEP) and adenosine triphosphate (ATP) revealed that the TP uncaging reactions were possible using visible light in the range $500-620 \mathrm{~nm}$. The authors also suggested that the TP uncaging is also possible in the range 550-720 nm under mild basic conditions, since the absorp- tion band is shifted to lower energy $(3.8 \mathrm{eV})$ in both the $\mathrm{OP}$ and $\mathrm{TP}$ absorption spectra.66c

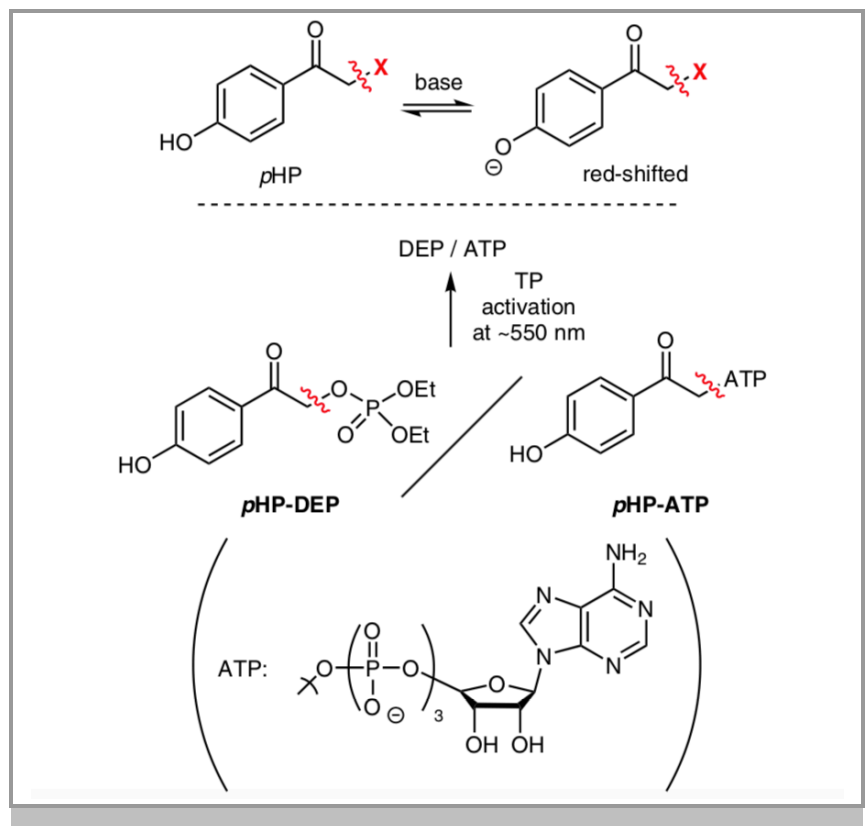

Scheme 8 TP uncaging of DEP and ATP using $p$-hydroxyphenacyl ( $p$ HP) PPG

\section{Our Contribution to TP Uncaging Reactions}

In collaboration with Professors Takayoshi Kobayashi (physicist) and Haruo Kasai (physiologist), the present authors Abe (organic chemist) and Katan (theoretical physi- cist) began investigating TP uncaging reactions in 2012 to better understand bioactive substrates in biological processes and clarify their roles. The target bioactive molecules were neurotransmitters such as glutamate (Glu), i.e., 2-aminopentanedioic acid.

Initially, the molecular design of TP-responsive PPGs was investigated. As noted in Section 2, the molecular size of TPresponsive chromophores should be small to enable water solubility and must also possess an appropriate TP absorption cross-section in the NIR region for utility in physiological experiments. Our target $\sigma 2$ value is at least over $100 \mathrm{GM}$ in the NIR region. Although the quantum yields $(\varphi \mathrm{u})$ are difficult to predict and refine, exceeding a quantum yield over $5 \%$ is achievable. The reported largest value of TP uncaging efficiency, $\delta \mathrm{u}=\sigma 2 \times \varphi \mathrm{u}$, was approximately $1 \mathrm{GM}$ when we began the study.

The stilbene core was selected as the platform to design a TP-responsive chromophore for physiological studies, be- cause stilbene derivatives have relatively large $\sigma 2$ values de- spite their compact structures. However, stilbene derivatives are linear compounds, thus, it is possible for cis/trans isomerization to occur via their electronically excited states, which would diminish the quantum yield of the un- caging process of bioactive molecules. Therefore, we decided to use cyclic 7,8dihydronaphthalene cores as the TP-responsive chromophores (Figure 6).68 As newcomers to this field, we initially chose the well-known $o$-nitrobenzyl (o- NB) PPG group on account of the strong electron-withdrawing ability of the nitro group. To 
impart water solubility to the chromophore, hydrophilic substituents such as carboxylic groups and polyethylene glycol units were introduced to the core structure.

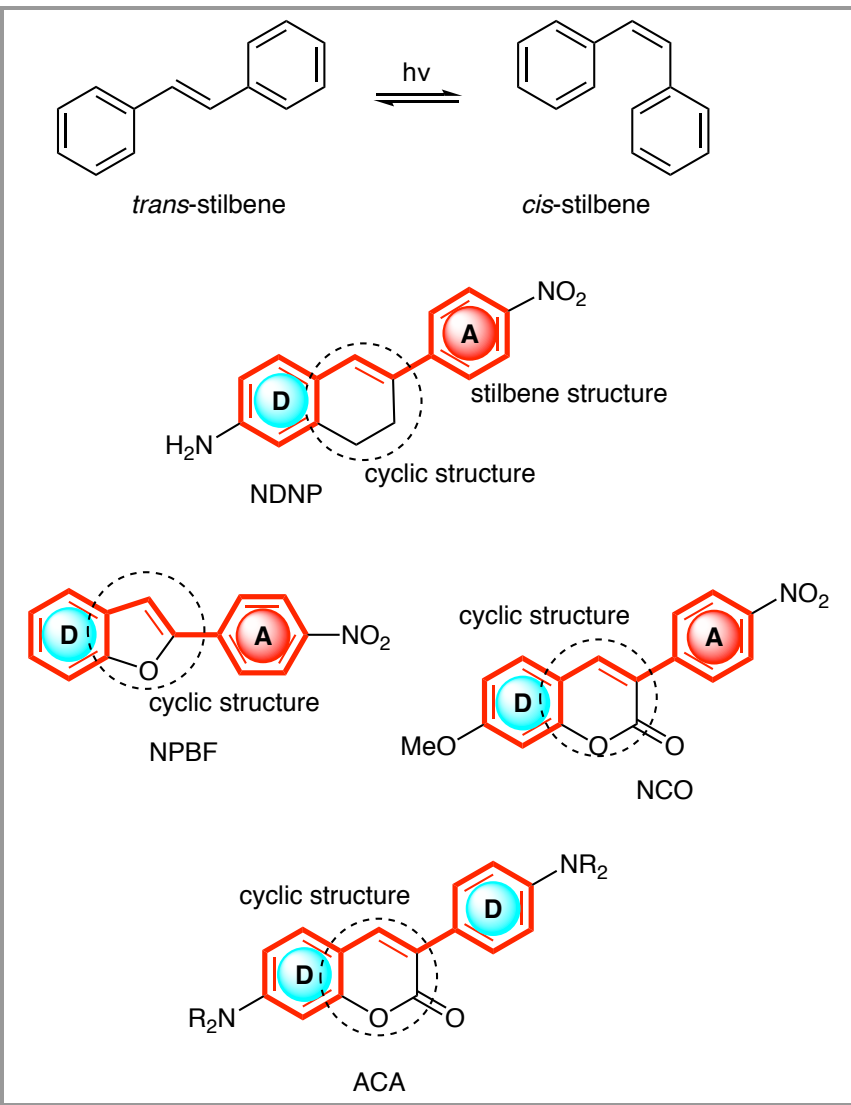

Figure 6 Our first molecular design for TP-responsive chromophores for physiological studies

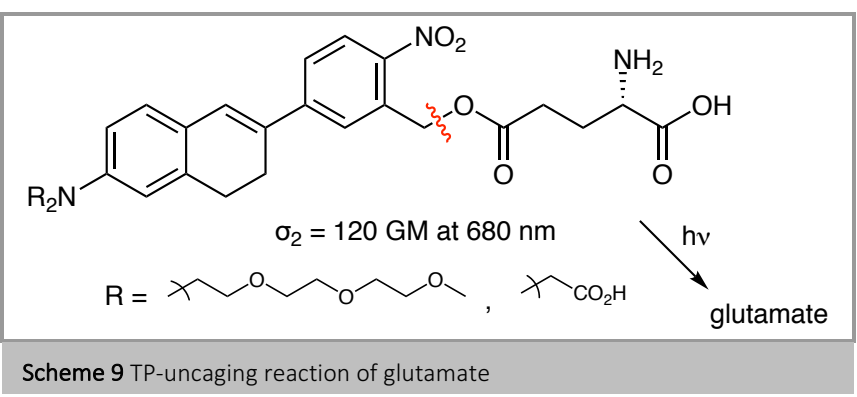

The TP absorption spectrum of the newly designed TP- responsive chromophore, 6-(4-nitrophenyl)-7,8-dihydronaphthalen-2-amine, was computed at the TD-B3LYP/6$31 \mathrm{G}(\mathrm{d})$ level of theory. The TP absorption maximum was predicted to be $150 \mathrm{GM}$ at $\sim 810 \mathrm{~nm}$. Therefore, the synthesis of the target molecules with a glutamate unit (Glu) began from 4bromo $\beta$-tetralone and 3-bromobenzaldehyde (Scheme 9). Clean formation of Glu was observed using OP and TP photolysis. However, the quantum yield of the un- caging reaction was low, $\varphi \mathrm{u}=0.01(1 \%)$.

Next, we designed a new TP-responsive chromophore, 2(4-nitrophenyl)benzofuran (NPBF) (Scheme 10).69 Previously, Ellis-Davies reported that the 3-nitrodibenzofuran (NDBF) core possessed a TP uncaging efficiency $(\delta \mathrm{u})$ of $0.6 \mathrm{GM}$ with a high quantum yield of $\varphi \mathrm{u}=0.7 .70$ The computed $\mathrm{TP}$ absorption maximum of the NPBF chromophore was found to be $150 \mathrm{GM}$ at $700 \mathrm{~nm}$, while that for the NDBF structure amounted to $75 \mathrm{GM}$ at $600 \mathrm{~nm}$ (i.e., twice smaller and blue-shifted). The TP uncaging efficiencies for the caged benzoic acid $(\varphi \mathrm{u}=0.09)$ and caged $\mathrm{Ca} 2+$ with EGTA structure $(\varphi \mathrm{u}=0.3)$ were determined to be 5 $\mathrm{GM}$ and $20.7 \mathrm{GM}$ at $740 \mathrm{~nm} \mathrm{TP}$ excitation, respectively. The NPBF chromophore was successfully applied in vivo for the caged $\mathrm{Ca} 2+$ ion.71

Subsequently, we investigated the donor-acceptor-substituted and donor-donor-substituted coumarin derivatives NC072 and ACA73 as dipolar and quadrupolar systems, respectively (Scheme 11). The dipolar system NCO (Figure 6) was found to possess a sizable TP absorption maximum at $700 \mathrm{~nm}$ with $150 \mathrm{GM}$. A more than four-fold increase with a small blueshift TP (700 GM at $650 \mathrm{~nm}$ ) was predicted for the quadrupolar analogue ACA. The corresponding caged benzoic acids NCO-BA and ACA-BA were synthesized and their TP uncaging reactions were conducted with NIR irra- diation. The TP uncaging efficiency for NCO-BA was found to be $3.4 \mathrm{GM}$ at $710 \mathrm{~nm}$, and $\sim 16 \mathrm{GM}$ at $650 \mathrm{~nm}$ for the quadrupolar system ACA-BA. This shows that quadrupolar structures are promising candidates for TP uncaging.<smiles>C#CCOC(=O)CCc1cc(-c2cc3ccccc3o2)ccc1C(CN(CC(C)=O)CC(C)=O)OCCOCCN(CC(C)=O)CC(C)=O</smiles>

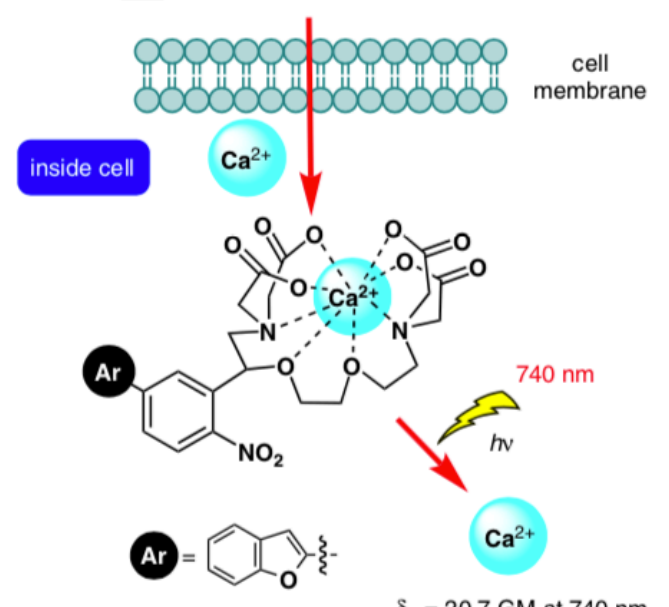

$\delta_{\mathrm{u}}=20.7 \mathrm{GM}$ at $740 \mathrm{~nm}$

Scheme 9 TP uncaging of $\mathrm{Ca}^{2+}$ using NPBF chromophore

\section{Summary}

In this short review, recent developments of near-infrared (NIR) two-photon (TP) induced photorelease (uncaging) of bioactive molecules such as drugs have been summa- rized. The TP excitation process at $650-1050 \mathrm{~nm}$ is useful for physiological studies in vivo, since the spatiotemporal release of bioactive molecules can be achieved with high 3D control conditions in 
deep areas of living tissues. The mo- lecular engineering of the next generation of chromophores suitable for the 'caging \& uncaging' technique should con- tribute to unravel more precisely the mechanisms of biolog-ical activity in vivo.

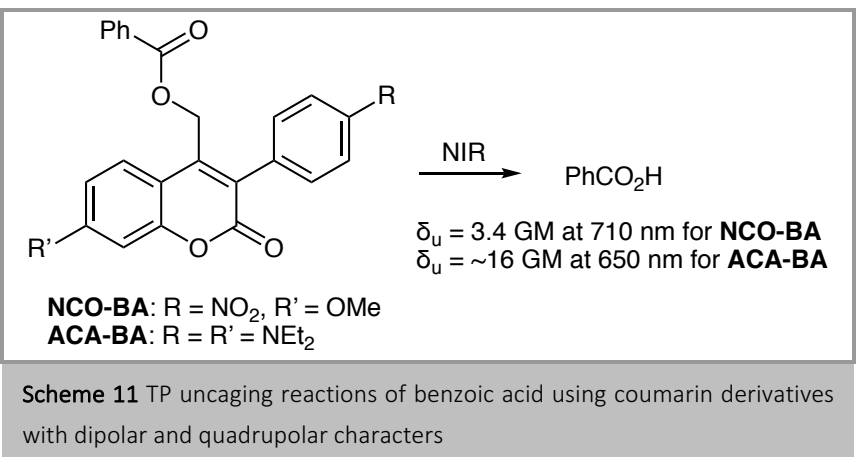

\section{Acknowledgment}

M.A. gratefully acknowledges financial support by a Grant-in-Aid for Scientific Research(B) (JP17H0302200). C.K. acknowledges the HPC resources of CINES and IDRIS under the allocations 2016[x2016080649] made by GENCI. The authors thank Graham C. R. EllisDavies, Alexandre Specht, Richard S. Givens and Peter I. Dalko for helpful suggestions during the preparation of this manuscript.

\section{References}

(1) Yuste, R. Nat. Methods, 2005, 2, 902.

(2) (a) In Fluorescence Microscopy, Cornea, A.; Conn, P. M. Eds. Elsevier, 2014. (b) Kim, H. M.; Cho, B. R. Small molecule twophoton probes for bioimaging applications. Chem. Rev. 2015, 115, 5014.

(3) In Dynamic Studies in Biology, Goeldner, M.; Givens, R. Eds., Wiley-VCH, 2005.

(4) Engels, J.; Schlager, E.-J. J. Med. Chem. 1977, 20, 907.

(5) Kaplan, H.; Forbush, B.; Hoffmann, J. F. Biochemistry, 1978, 17, 1929.

(6) Barltrop, J. A.; Schofield, P. Tetrahedron Lett. 1962, 3, 697-699.

(7) Givens, R. S.; Conrad, III, P. G.; Yousef, A. L.; Lee, J.-I., In CRC Handbook of Organic Photochemistry and Photobiology 2nd Ed., Boca Raton, CRC Press, Chap. 69.

(8) Bochet, C. G., J. C. S. Perkin Trans. 2002, 1, 125.

(9) Hoffmann, N. Chem. Rev. 2008, 108, 1052

(10) Wang, P. Asian J. Org. Chem. 2013, 2, 452.

(11) Klán, P.; Šolomek, T.; Bochet, C. G.; Blanc, A.; Givens, R.; Rubina, M.; Popik, V.; Kostikov, A.; Wirz, J. Chem. Rev. 2013, 113, 119.

(12) Barltrop, J. A.; Plant, P. J.; Schofield, P. Chem. Comm. 1966, 822.

(13) Patchornik, A.; Amit, B.; Woodward, R. B. J. Am. Chem. Soc. 1970, 92, 6333.

(14) Il'ichev, Y. V.; Schwörer, M. A.; Wirz, J. J. Am. Chem. Soc. 2004, 126, 4581.

(15) Hasan, A.; Stengele, K.-P.; Giegrich, H.; Cornwell, P.; Isham, K. R.; Sachleben, R. A.; Pfleiderer, W.; Foote, R. S. Tetrahedron. 1997, 53, 4247.

(16) Gug, S.; Charon, S.; Specht, A.; Alarcon, K.; Ogden, D.; Zietz, B.; Leonard, J.; Haacke, S.; Bolze, F.; Nicoud, J.-F.; Goeldner, M. ChemBioChem. 2008, 9, 1303.

(17) a) Donato, L.; Mourot, A.; Davenport, C. M.; Herbivo, C.; Warther, D.; Lonard, J.; Bolze, F.; Nicoud, J.-F.; Kramer, R. H.; Goeldner, M.; Specht, A. Angew. Chem. Int. Ed. 2012, 51, 1840.

(18) Specht, A.; Bolze, F.; Donato, L.; Herbivo, C.; Charon, S.; Warther, D.; Gug, S.; Jean-FranÅois, N.; Goeldner, M. Photochem. Photobiol. Sci. 2012, 11, 578.

(19) Amit, B.; Patchornik, A. Tetrahedron Lett. 1973, 14, 2205.

(20) Amit, B.; Ben-Efraim, D. A.; Patchornik, A. J. Am. Chem. Soc.1976, $98,843$.
(21) (a) Morrison, J.; Wan, P.; Corrie, J. E. T.; Papageorgiou, G. Photochem. Photobiol. Sci. 2002, 1, 960. (b) Cohen, A. D.; Helgen, C.; Bochet, C. G.; Toscano, J. P. Org. Lett. 2005, 7, 2845. (c) Corrie, J. E. T.; Barth, A.; Papageorgiou, G. J. Labelled Compd. Radiopharm. 2001, 44, 619.

(22) Pass, S.; Amit, B.; Patchornik, A. J. Am. Chem. Soc. 1981, 103, 7674.

(23) Papageorgiou, G.; Ogden, D. C.; Barth, A.; Corrie, J. E. J. Am. Chem. Soc. 1999, 121, 6503.

(24) Matsuzaki, M.; Hayama, T.; Kasai, H.; Ellis-Davies, G. C. R. Nat. Chem. Biol. 2010, 6, 255

(25) Givens, R. S.; Matuszewski, B. J. Am. Chem. Soc. 1984, 106, 6860.

(26) Kamatham, N.; Mendes, D. C.; Da Silva, J. P.; Givens, R. S.; Ramamurthy, V. Org. Lett. 2016, 18, 5480.

(27) Fedoryak, O. D.; Dore, T. M. Org. Lett. 2002, 4, 3419.

(28) Zhu, Y.; Pavlos, C. M.; Toscano, J. P.; Dore, T. M. J. Am. Chem. Soc. 2006, 128, 4267.

(29) Davis, M. J.; Kragor, C. H.; Reddie, K. G.; Wilson, H. C.; Zhu, Y.; Dore, T. M. J. Org. Chem. 2009, 74, 1721.

(30) Li, Y. M.; Shi, J.; Cai, R.; Chen, X. Y.; Guo, Q. X.; Liu, L. Tetrahedron Lett. 2010, 51, 1609.

(31) Kitani, S.; Sugawara, K.; Tsutsumi, K.; Morimoto, T.; Kakiuchi, K. Chem. Commun. 2008, 18, 2103.

(32) (a) Goswami, P. P.; Syed, A.; Beck, C. L.; Albright, T. R.; Mahoney, K. M.; Unash, R.; Smith, E. A.; Winter, A. H. J. Am. Chem. Soc. 2015, 137, 3783-3786. (b) Palao, E.; Slanina, T.; Muchová, L.; Šolomek, T.; Vítek, L.; Klán, P. J. Am. Chem. Soc. 2016, 138, 126-133.

(33) Denk, W.; Stricker, J. H.; Webb, W. W. Science, 1990, 248, 73.

(34) Denk, W.; Proc. Natl. Acad. Sci. USA 1994, 91, 6629.

(35) Lipp, P.; Niggli, J. Physiol. 1998, 508, 801.

(36) Furuta, T.; Wang, S. S.-H.; Dantzker, J. L.; Dore, T. M.; Bybee, W. J.; Callaway, E. M.; Denk, W.; Tsien, R. Y. Proc. Natl. Acad. Sci. U.S.A. 1999, 96, 1193-1200.

(37) Matsuzaki, M.; Ellis-Davies, G. C. R.; Nemoto, T.; Miyashita, Y.; Iino, M.; Kasai, H. Nat. Neurosci. 2001, 4, 1086.

(38) Göppert-Mayer, M. Ann. Phys. 1931, 401, 273-294.

(39) Boyd, W. In Non-Linear Optics, 2nd ed., Elsevier, London, 2003.

(40) Maruo, S.; Nakamura, O.; Kawata, S. Opt. Lett. 1997, 22, 132.

(41) Kawata, S.; Sun, H.-B, Tanaka, T.; Takada, K. Nature 2001, 412, 697.

(42) Mayer, G.; Heckel, A. Angew. Chem. Int. Ed. 2006, 45, 4900-4921.

(43) Specht, A.; Bolze, F.; Omran, Z.; Nicoud, J.-F.; Goeldner, M. Hfsp J. 2009, 3, 255-264.

(44) Pawlicki, M.; Collins, H. A.; Denning, R. G.; Anderson, H. L. Angew. Chem. Int. Ed. 2009, 48, 3244-3266.

(45) Ellis-Davies, G. C. R. Two-Photon microscopy for chemical neuroscience. ACS Chem. Neurosci. 2011, 2, 185-197.

(46) Zhao, Y. Macromolecules, 2012, 45, 3647-3657.

(47) Brieke, C.; Rohrbach, F.; Gottschalk, A.; Mayer, G.; Heckel, A. Angew. Chem. Int. Ed. 2012, 51, 8446-8476.

(48) Bort, G.; Gallavardin, T.; Ogden, D.; Dalko, P. I. Angew. Chem. Int. Ed. 2013, 52, 4526-4537.

(49) Piant, S.; Bolze, F.; Specht, A. Opt. Mat. Exp. 2016, 1679-1691.

(50) Terenziani, F.; Katan, C.; Badaeva, E.; Tretiak, S.; Blanchard-Desce, M. Adv. Mater. 2008, 20, 4641-4678.

(51) Tretiak, S. ; Chernyak, V. J. Chem. Phys. 2003, 119, 8809.

(52) Xue, B.; Katan, C.; Bjorgaard, J. A.; Kobayashi, T. AIP Adv., 2015, 5, 12.

(53) Weisz, S. Z.; Zahlan, A. B.; Gilreath, J.; Jarnagin, R. C.; Silver, M. J. Chem. Phys. 1964, 41, 3491-3495.

(54) Anderson, R. J. M.; Holtom, G. R.; McClain, W. M. J. Chem. Phys. 1979, 70, 4310-4315.

(55) Katan, C.; Terenziani, F.; Le Droumaguet, C.; Mongin, O.; Werts, M. H. V., Tretiak, S.; Blanchard-Desce, M. Branching of Dipolar Chromophores: Effects on Linear and Nonlinear Optical Properties, Proc. SPIE 5935, Linear and Nonlinear Optics of Organic Materials V, 593503 (September 02, 2005); doi:10.1117/12.618464.

(56) Albota, M.; Beljonne, D.; Brédas, J. L.; Ehrlich, J. E.; Fu, J. Y.; Heikal, A. A.; Hess, S. E.; Kogej, T.; Levin, M. D.; Marder, S. R.; Maughon, D. 
M. C.; Perry, J. W.; Röckel, H.; Rumi, M.; Subramaniam, G.; Webb, W. W.; Wu, X. L.; Xu, C. Science, 1998, 281, 1653-1656.

(57) Mongin, O.; Porrs, L.; Charlot, M.; Katan, C.; Blanchard-Desce, M. Chem. Eur. J. 2007, 13, 1481 - 1498.

(58) Katan, C.; Charlot, M.; Mongin, O.; Le Droumaguet, C.; Jouikov, V.; Terenziani, F.; Badaeva, E.; Tretiak, S.; Blanchard-Desce, M. J. Phys. Chem. B 2010, 114, 3152

(59) Hayashi, K.-I.; Kusaka, N.; Yamasaki, S.; Zhao, Y.; Nozaki, H. Bioorg. Med. Chem. Lett. 2015, 25, 4464-4471.

(60) Korzycka, K. A.; Bennett, P. M.; Cueto-Diaz, E. J.; Wicks, G.; Drobizhev, M.; Blanchard-Desce, M.; Rebane, A. Anderson, H. L. Chem. Sci. 2015, 6, 2419-2426.

(61) Tran, C.; Gallavardin, T.; Petit, M.; Slimi, R.; Dhimane, H.; Blanchard-Desce, M.; Acher, F. C.; Ogden, D.; Dalko, P. I. Org. Lett. 2015, 17, 402-405.

(62) Cueto Diaz, E. J.; Picard, S.; Chevasson, V.; Daniel, J.; Hugues, V.; Mongin, O.; Genin, E.; Blanchard-Dedcs, M. Org. Lett, 2015, 17, 102-105.

(63) Agarwal, H. K.; Janicek, R.; Chi, S.-H.; Perry, J. W.; Niggli, E.; EllisDavies, G. C. R. J. Am. Chem. Soc. 2016, 138, 3687-3693.

(64) Richers, M. T.; Amatrudo, J. M.; Olson, J. P.; Ellis-Davies, G. C. R. Angew. Chem. Int. Ed. 2017, 56, 193-197.

(65) Fichte, M. A. H.; Weyel, X. M. M.; Junek, S.; Schäfer, F.; Herbivo, C.; Coeldner, M.; Specht, A.; Wachtveitl, J.; Heckel, A. Angew. Chem. Int. Ed. 2016, 55, 8948-8952.

(66) (a) Givens, R. S.; Park, C. H. Tetrahedron Lett. 1996, 37, 6259. (b) Park, C. H.; Givens, R. S. J. Am. Chem. Soc. 1997, 119, 2453. (c) Klicova, L.; Sebej, P.; Solomek, T.; Hellrung, B.; Slavicek, P.; Klan, P.; Heger, D.; Wirz, J. J. Phys. Chem. A 2012, 116, 2935.

(67) Houk, A.; Givens, R. S.; Elles, C. G. J. Phys. Chem. B 2016, 120, 3178.

(68) Boinapally, S.; Huang, B.; Abe, M.; Katan, C.; Noguchi, J.; Watanabe, S.; Kasai, H.; Xue, B.; Kobayashi. T. J. Org. Chem. 2014, 79, 78227830.
(69) Komori, N.; Jakkampudi, S.; Motoishi, R.; Abe, M.; Kamada, K.; Furukawa, K.; Katan, C.; Sawada, W.; Takahashi, N.; Kasai, H.; Xue, B.; Kobayashi, K. Chem Commun 2016, 52, 331-334.

(70) Momotake, A.; Lindegger, N,; Niggli, E.; Barsotti R. J.; Ellis-Davies, G. C. R. Nat. Methods, 2006, 3, 35-40.

(71) Jakkampudi, S.; Abe, M.; Komori, N.; Takagi, R.; Furukawa, K.; Katan, C.; Sawada, W.; Takahashi, N.; Kasai, H. ACS Omega, 2016, 1,193-201.

(72) Chitose, Y.; Abe, M.; Furukawa, K.; Katan, C. Chem. Lett. 2016, 45, 1186-1188.

(73) Chitose, Y.; Abe, M.; Furukawa, K.; Lin, J.-Y.; Lin, T.-C.; Katan, C. Org. Lett. 2017, 19, 2622.

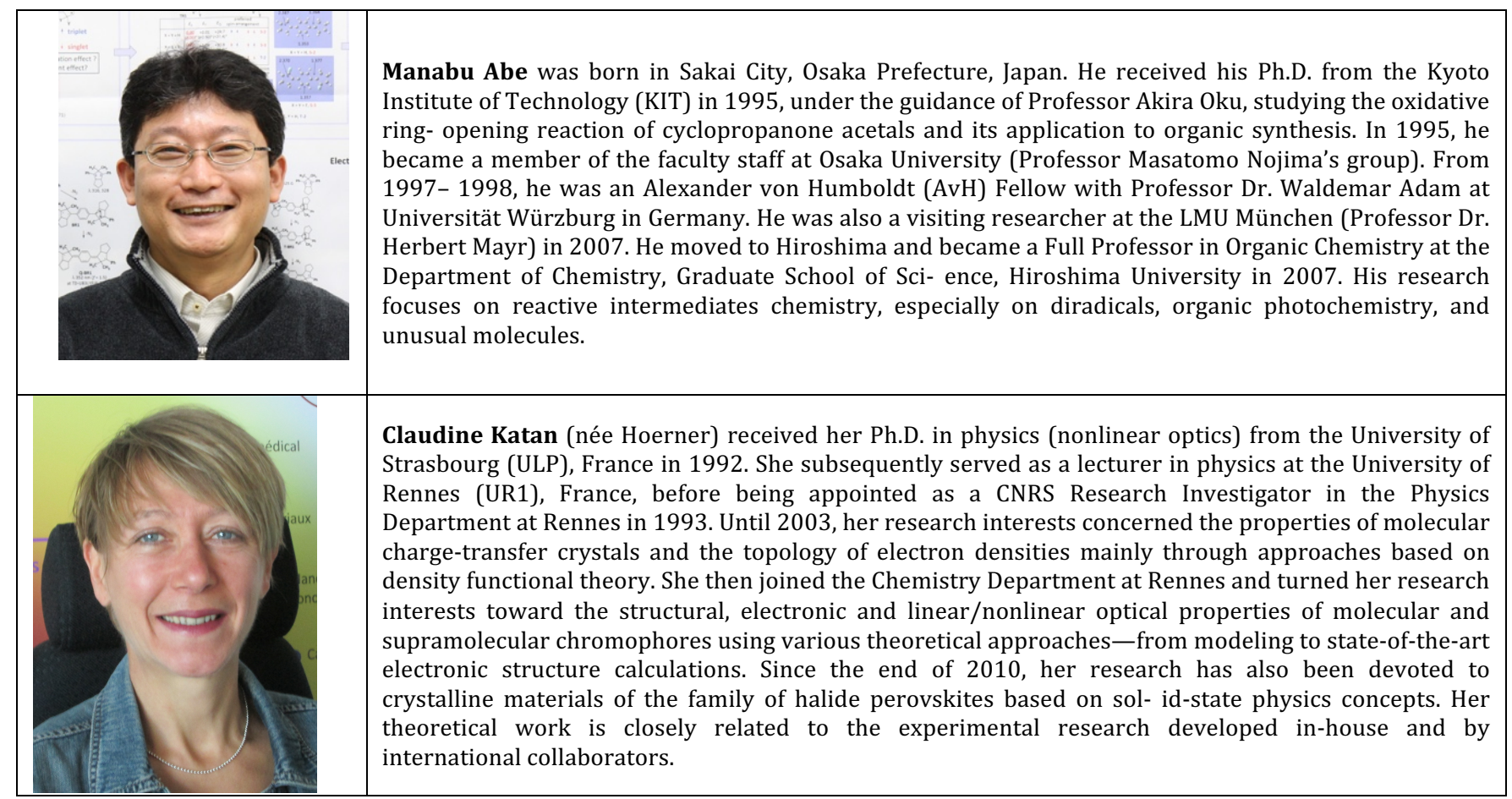

